\title{
PREVENTION OF STAFF BURNOUT IN HUMANITIES TEACHERS OF HIGHER EDUCATIONAL INSTITUTIONS
}

\author{
Polunina NV, Soltamakova LS $\bowtie$
}

Department of Public Health, Healthcare and Healthcare Economics,

Pirogov Russian National Research Medical University, Moscow

\begin{abstract}
In their daily life teachers go through a lot of stress ensuing from abrasive relationships with the administrative staff, colleagues or students, and family conflicts. Long-term exposure to stressors leads to the syndrome of emotional burnout, which can be avoided is preventive care is taken. The aim of this study was to identify burnout symptoms in the humanities teachers working for higher educational institutions and to propose adequate preventive measure. We recruited 1,489 teachers who were offered to anonymously fill out a questionnaire and also collected information about their health from sickness leaves. Statistical analysis included calculation of means, their errors, intensive and extensive variables, and confidence intervals. Two in three teachers reported fatigue, regular back/chest pain, and headache. The use of a scoring scale allowed us to conclude that a lot of respondents (43.2\%) had severe burnout symptoms. Every second teacher demonstrated poor health awareness. To prevent staff burnout, measures should be taken aimed at stimulating a positive attitude to medical care, improving health literacy and motivating teachers to lead a healthy lifestyle.
\end{abstract}

Keywords: teacher, staff burnout, professional occupation, health awareness, prevention

$\triangle$ Correspondence should be addressed: Liana S. Soltamakova

Ostrovityanova 1, Moscow, 117997; 06doctor06@mail.ru

Received: 05.08.2018 Accepted: 26.10.2018

DOI: $10.24075 /$ brsmu.2018.059

\section{ПРОФИЛАКТИКА СИНДРОМА ЭМОЦИОНАЛЬНОГО ВЫГОРАНИЯ У ПРЕПОДАВАТЕЛЕЙ ГУМАНИТАРНЫХ ВЫСШИХ УЧЕБНЫХ ЗАВЕДЕНИЙ}

Н. В. Полунина, Л. С. Солтамакова $\bowtie$

Кафедра общественного здоровья и здравоохранения, экономики здравоохранения,

Российский национальный исследовательский университет имени Н. И. Пирогова, Москва

\begin{abstract}
Профессиональная деятельность преподавателей сопряжена с воздействием большого числа стресс-фракторов, которые могут проявляться на работе, во взаимоотношениях с начальством, напряженной обстановкой в коллективе, вследствие различных социально-психологических переживаний на работе и дома. Длительное воздействие этих факторов способствует развитию синдрома эмоционального выгорания, профилактика которого просто необходима. Целью исследования было выявить симптомы синдрома эмоционального выгорания у преподавателей гуманитарных высших учебных заведений и разработать мероприятия по его просилактике. Обследовано 1489 преподавателей гуманитарных вузов с помощью составленных анонимных анкет для изучения профессиональной деятельности педагогов, а также выборочных карт на основании листков нетрудоспособности. Для статистического анализа рассчитывали средние величины и их ошибки, интенсивные и экстенсивные показатели; использовали метод сравнения относительных величин и определение достоверности различия. Выявлено, что у двух преподавателей из трех присутствуют чувство усталости, частые боли в спине и груди, головная боль. В результате балльной оценки степени выраженности данных симптомов обнаружено, что большая часть преподавателей (43,2\%) оказалась в группе с высоким уровнем психоэмоционального выгорания. У каждого второго преподавателя наблюдается низкий уровень медицинской активности. Для профилактики синдрома эмоционального выгорания необходимо внедрение мероприятий, направленных на формирование позитивной медицинской активности, повышение медицинской грамотности и воспитание навыков здорового образа жизни.
\end{abstract}

Ключевые слова: преподаватель, синдром эмоционального выгорания, профессиональная деятельность, медицинская активность, профилактика

$\triangle$ Для корреспонденции: Лиана Солтамаковна Солтамакова ул. Островитянова, д. 1, г. Москва, 117997; 06doctor06@mail.ru

Статья получена: 05.08.2018 Статья принята к печати: 26.10.2018 DOI: $10.24075 /$ vrgmu.2018.059

Our everyday work affects our health and to a greater or lesser extent shapes our lifestyle, mentality and personality [1-3]. Extensive research into occupational risk factors reveals the need for special measures aimed at preventing workassociated health risks [4-6].

A lot of published articles focus on how work overload affects the health of white-collar workers causing stress and stress-related conditions [7, 8]. For example, a few research studies have attempted to assess the impact of workload in an optimized work environment [9]. Some authors have proposed algorithms for improving the efficiency of intellectual labor and ease its burden based on cognitive semantics [10].

A number of authors have studied the occupational health of teachers. It has been shown that many teachers suffer from chronic diseases, but only 2 in 3 teachers undergo regular medical checkups [11, 12]. The most common chronic 
disorders observed in teachers are hypertension, chronic laryngotracheitis, and varicose veins. Among the most prevalent acute conditions are respiratory infections, laryngitis, and acute laryngotracheitis. Many of these diseases are occupational and can be caused by voice overuse and serious psychological and emotional strain.

There are a lot of stressors intrinsic to the teaching job ensuing from the necessity to always be in contact with students encouraging them to acquire new knowledge and build professional skills. The teacher guides the student in his/ her intellectual and emotional pursuits. In its essence, teaching is all about interacting with people, understanding them and helping them to channel their efforts towards achieving the goals set by the society and the state [13].

The modern teacher goes through a lot of stress trying to solve problems arising from the interaction with their colleagues, students and administrative staff. Stress affects the quality of teachers' work, their personality, relationships with colleagues, and takes a huge toll on his/her professional and private life. Working with people demands professional expertise, knowledge of psychology and sociology; it also poses a high risk of emotional distress and can eventually lead to the symptoms of emotional burnout.

The burnout syndrome (BS) is the body's response to longterm exposure to occupational stress factors. The term "staff burnout" was first used in 1974 by the American psychiatrist H. J. Fruedenberger to describe the emotional state of healthy individuals who were in long, close contact with emotionally unstable clients and patients. Fruedenberger saw this syndrome as a complex psychophysiological phenomenon implicated in emotional, mental and physical exhaustion that manifests itself as depression, fatigue, a feeling of being drained, a lack of energy and enthusiasm, an inability to value one's own accomplishments and achievements, poor workplace morale, and dissatisfaction with life $[14,15]$. The social psychologist K. Maslac describes this syndrome as physical and emotional exhaustion characterized by low self-esteem, negativity, a lack of understanding and empathy to clients and patients. BS is a mechanism of psychological defense based on the complete or partial emotional withdrawal in response to a traumatic event [16].

The literature does not provide information about BS in teachers working for higher educational institutions, its causes and the impact it has on teachers' health. The aim of this study was to identify and investigate the symptoms of BS in humanities teachers employed by higher educational institutions and to propose measures for preventing the negative impact of BS on health.

\section{METHODS}

To study BS manifestations and its effect on health, we recruited 1,489 teachers of both sexes aged from 25 years and older who had been working in their current jobs for at least 5 years. The participants were asked to anonymously fill out and immediately submit an electronic questionnaire containing 85 questions devised to assess their professional skills, psychological state and the severity of BS symptoms. Health-related information was obtained by analyzing sickness leaves. Statistical processing included calculation of means and mean errors, intensive and extensive variables and their errors, comparison of relative values, computation of confidence intervals and Pearson's correlation coefficients.

\section{RESULTS}

Among the teachers working for higher educational institutions the most common BS symptoms were fatigue, headache, chest or back pain, excess weight, low productivity, bad memory, difficulty concentrating, and sleep problems (Table 1).

On average, every teacher had 4 to 5 symptoms of burnout. Almost every second teacher complained of fatigue, headache, excess weight and sleep problems.

All symptoms typical for BS were rated by the participants depending on how pronounced they were on the scale of 0 (no symptoms) to 5 (severe symptoms). The minimum score was 6 points, the maximum score was 40 points. Depending on the total score, the teachers were distributed into 3 groups: mild burnout (0-12 points), moderate burnout (13 to 26 points), and severe burnout (27 to 40 points). Details are provided in Table 2.

The above listed symptoms of BS are often preceded by emotional distress. In our study almost every second teacher was emotionally labile (46.8\%), moody, irritable, anxious, and had difficulty concentrating. About one in 3 teachers complained of feeling unwell. On average, every teacher had 1 or 2 symptoms indicative of emotional distress.

The comparative analysis of questionnaires revealed that teachers with severe BS complained of negative emotional symptoms more often than other participants (Table 3).

Table 1. Burnout symptoms in the teachers working for higher educational institutions

\begin{tabular}{|c|l|c|}
\hline № & \multicolumn{1}{|c|}{ Burnout symptoms } & Incidence per 100 participants \\
\hline 1 & Fatigue & 67.4 \\
\hline 2 & Chest or back pain & 64.2 \\
\hline 3 & Headache & 62.4 \\
\hline 4 & Excess weight & 58.1 \\
\hline 5 & Reduced productivity & 53.2 \\
\hline 6 & Sleep problems & 50.9 \\
\hline 7 & Bad memory. difficulty concentrating & 49.5 \\
\hline 8 & Sleepiness at daytime & 47.1 \\
\hline
\end{tabular}

Table 2. Distribution of humanities teachers into groups based on the severity of burnout symptoms

\begin{tabular}{|l|c|c|}
\hline \multicolumn{1}{|c|}{ Severity of burnout syndrome } & Points scored & Percentage of participants, \% \\
\hline Mild & $>12$ & 19.4 \\
\hline Moderate & $13-26$ & 37.4 \\
\hline Severe & $27-40$ & 43.2 \\
\hline Total & & 100 \\
\hline
\end{tabular}


In our study the sample was dominated by women (67.4\%) aged $51.4 \pm 0.7$ years on average; $28.7 \%$ of the surveyed teachers were younger than $40 ; 31.7 \%$ of teachers were older than 60 years. The reported teaching experience was $23.1 \pm 0.4$ years on average; $24.2 \%$ of the respondents had 10 years of teaching experience while $36.4 \%$ of the respondents had been teaching for over 30 years. The majority of the surveyed teachers (62.4\%) had only one job throughout their carrier.

The teachers older than 60 had BS symptoms more often than their younger $(<40$ years) counterparts. Older teachers felt sleepiness at daytime, back and chest pains, and complained of deteriorating memory, difficulty concentrating, fatigue, and excess weight 2.8-2.4 times more often than other participants (Table 4).

The analysis has revealed a direct correlation between the symptoms of BS and the length of teaching experience $(r=0.576 ; m= \pm 0.034 ; p<0.05)$ in the surveyed humanities teachers. Individuals who had over 30 years of teaching experience complained of SB symptoms more often than those who had less than 10 years of experience $(p<0.05)$ (Table 5).

Apart from BS symptoms we analyzed the atmosphere in the workplace and in the teachers' families.

We have established that the atmosphere in the family and in the workplace largely contributes to emotional burnout. Among the stressors we accounted for were strong heavy emotions, relationships with colleagues, students and relatives.

Every teacher was able to remember an episode in their professional or private life that led to a stressful or hostile atmosphere in the workplace or family. Among the most commonly reported problems were family conflicts with a spouse or relatives. One in five teachers had conflicts with colleagues, administrative staff and students. One in every five teachers reported a serious illness as a factor negatively affecting their morale (Table 6).

The comparative analysis showed than the teachers with severe BS symptoms reported stressors affecting the atmosphere in the workplace or family more often than those with mild symptoms of BS (Table 6).
The factors listed above contribute to psychological stress and compromise teachers' health.

Emotional burnout is a complex psychophysiological phenomenon defined as emotional, mental and physical exhaustion manifested as fatigue, depression, inability to notice and value one's own accomplishments and achievements, negativity, and dissatisfaction with life.

To neutralize the effect of negative factors, a teacher has to be able to switch off from work-related problems and engage in other types of activities in leisure time.

Our study demonstrates that the considerable proportion of teachers lack physical activity, eat unhealthy diet or take their meals irregularly, do not watch their weight, and use sleeping pills without doctor's permission (Table 7). Although the majority of the respondents had burnout symptoms, only one in every 4 teachers sought medical advice and only $39.6 \%$ of the respondents actually followed that advice.

On average, every teacher demonstrated $4.27 \pm 0.32$ signs of poor health awareness. The teachers with severe BS symptoms showed $4.96 \pm 0.35$ negative signs, while those in the group with mild BS symptoms showed only $3.12 \pm 0.31$ signs, which is significantly less.

The comparative analysis (Table 7) showed that the teachers with severe burnout syndrome did not see a doctor 3.1. times more often than others; slept less 1.9 times more often, took medications without consulting a doctor 1.7 times more often, did not watch their weight 1.5 times more often, tended to lead a sedentary lifestyle 1.5 times more often; besides they were not satisfied with night's sleep quality and did not follow medical advice.

The group with poor health awareness consisted of teachers who demonstrated 6 or more such signs. Among the teachers with severe symptoms of BS 68.5\% demonstrated low health awareness; among those with mild symptoms of BS there were 1.9 more such individuals, which means that their attitude to medicine and health in general needs to be changed.

Table 3. Frequency of symptoms of psychoemotional distress in humanities teachers (per 100 participants)

\begin{tabular}{|c|c|c|c|c|}
\hline \multirow{3}{*}{ Symptoms of psychoemotional distress } & \multicolumn{3}{|c|}{ Per 100 teachers } & \multirow{3}{*}{$\begin{array}{c}\text { Probability of accurate } \\
\text { prediction } p\end{array}$} \\
\hline & \multirow{2}{*}{ In total } & \multicolumn{2}{|c|}{ Severity of burnout syndrome } & \\
\hline & & mild & severe & \\
\hline Emotional lability & 39.3 & 29.8 & 38.8 & $<0.01$ \\
\hline Unstable mood & 37.3 & 27.2 & 37.4 & $<0.01$ \\
\hline Reduced attention span & 32.1 & 23.9 & 30.3 & $<0.05$ \\
\hline Irritability & 29.7 & 19.9 & 29.5 & $<0.01$ \\
\hline Anxiety & 24.2 & 15.9 & 22.5 & $<0.05$ \\
\hline Feeling of unwellness & 29.1 & 21.7 & 26.5 & $>0.05$ \\
\hline
\end{tabular}

Table 4. Burnout symptoms in humanities teachers depending on their age

\begin{tabular}{|c|l|c|c|c|}
\hline \multirow{2}{*}{ № } & \multicolumn{2}{|c|}{ Burnout symptoms } & \multicolumn{2}{c|}{ Incidence per 100 teachers } \\
\cline { 3 - 4 } & & $<40$ years of age & $>60$ years of age & \multirow{2}{*}{ Probability of accurate prediction $p$} \\
\hline 1 & Fatigue & 36.5 & 86.3 & $<0.01$ \\
\hline 2 & Chest or back pain & 32.1 & 84.3 & $<0.01$ \\
\hline 3 & Headache & 42.9 & 69.9 & $<0.05$ \\
\hline 4 & Excess weight & 29.7 & 74.5 & $<0.01$ \\
\hline 5 & Reduced productivity & 33.8 & 60.6 & $<0.05$ \\
\hline 6 & Sleep problems & 34.9 & 54.9 & $<0.05$ \\
\hline 7 & Bad memory, difficulty concentrating & 24.3 & 62.7 & $<0.01$ \\
\hline 8 & Sleepiness at daytime & 21.6 & 60.6 & $<0.01$ \\
\hline
\end{tabular}




\section{DISCUSSION}

In this work we attempted to study the symptoms of staff burnout in the humanities teachers employed by higher educational institutions. It has been established that about 2 in every 3 teachers suffer from fatigue, regular pain in the chest or back, and headaches. This leads to reduced productivity in the workplace, deteriorating memory and the inability to concentrate. Teachers often have sleep problems and complain of daytime sleepiness. As a rule, such teachers (58.1\%) are overweight.

The use of a scoring scale allowed us to distribute the participants into 3 groups: severe symptoms of emotional burnout (27 to 40 points), mild symptoms (0 to 12 points), and moderate symptoms (13 to 26 points). Unfortunately, the majority of the respondents (43.2\%) constituted a group with severe burnout syndrome. Only one in five teachers had mild symptoms of this condition.

Analysis of the social and psychological background of the teachers has revealed that our sample is dominated by women aged $51.4 \pm 0.7$ with a teaching experience of $23.1 \pm 0.4$ years. The majority of the teachers have had only one job in their professional life. The burnout syndrome is more often observed in the teachers older than 60 with a teaching experience of over 30 years.
A stressful atmosphere in the workplace or family also contributes to the development of burnout symptoms. Every teacher reported episodes that created a hostile or stressful atmosphere in their families or workplace. However, the teachers who suffered from severe BS symptoms reported stressful atmosphere more often than those whose symptoms were mild.

Special attention should be paid to health awareness demonstrated by the teachers. Almost every second teacher with severe BS symptoms has a negative attitude to their health. They lead a sedentary lifestyle, follow an unhealthy diet, eat irregularly, do not have enough sleep, rarely consult a doctor or follow medical advice, take unprescribed medications, and are overweight. Considering the fact that staff burnout is a sign of emotional, physical and mental exhaustion, we need to neutralize the effect of negative factors and to promote health awareness among teachers. The respondents demonstrate poor health literacy $(69.7 \%)$, a lack of motivation to lead a healthy lifestyle (47.2\%), poor knowledge of the roles of night's sleep quality (46.2\%), physical activity (43.1\%), and nutrition (39.7\%), unwillingness to consult their doctors (39.6\%) or follow medical advice (34.1\%).

Preventive care should be provided by medical personnel and aim at improving health literacy, stimulating teachers to change their attitude to health and follow medical advice.

Table 5. Burnout symptoms in humanities teachers depending on their teaching experience

\begin{tabular}{|c|c|c|c|c|}
\hline \multirow{2}{*}{ № } & \multirow{2}{*}{ Burnout symptoms } & \multicolumn{2}{|c|}{ Incidence per 100 teachers } & \multirow{2}{*}{$\begin{array}{l}\text { Probability of accurate } \\
\text { prediction } p\end{array}$} \\
\hline & & Less than 10 years of teaching experience & Over 30 years of teaching experience & \\
\hline 1 & Fatigue & 29.2 & 90.6 & $<0.001$ \\
\hline 2 & Chest or back pain & 27.9 & 85.5 & $<0.001$ \\
\hline 3 & Headache & 34.1 & 75.7 & $<0.05$ \\
\hline 4 & Excess weight & 19.6 & 81.6 & $<0.001$ \\
\hline 5 & Reduced productivity & 32.8 & 58.6 & $<0.05$ \\
\hline 6 & Sleep problems & 35.1 & 51.7 & $<0.05$ \\
\hline 7 & Bad memory, difficulty concentrating & 23.4 & 60.6 & $<0.01$ \\
\hline 8 & Sleepiness at daytime & 21.8 & 57.4 & $<0.01$ \\
\hline
\end{tabular}

Table 6. Stressors in the workplace or family per 100 teachers

\begin{tabular}{|c|c|c|c|c|c|}
\hline \multirow{2}{*}{ № } & \multirow{2}{*}{ Stressors in the workplace or family } & \multirow{2}{*}{$\begin{array}{l}\text { Incidence per } \\
100 \text { teachers }\end{array}$} & \multicolumn{2}{|c|}{ Burnout syndrome } & \multirow{2}{*}{$\begin{array}{c}\text { Probability of accurate } \\
\text { prediction } p\end{array}$} \\
\hline & & & Severe & Mild & \\
\hline 1 & Frequent conflicts with a spouse & 25.5 & 36.2 & 14.7 & $<0.01$ \\
\hline 2 & Frequent conflicts with close relatives & 24.7 & 36.4 & 12.9 & $<0.01$ \\
\hline 3 & Frequent conflicts with colleagues or administrative staff & 21.6 & 29.2 & 13.9 & $<0.01$ \\
\hline 4 & Frequent conflicts with students & 21.2 & 31.9 & 10.4 & $<0.01$ \\
\hline 5 & Health problems & 20.8 & 32.7 & 8.9 & $<0.01$ \\
\hline 6 & Serious illness or death of a close friend/relative & 15.2 & 18.6 & 11.8 & $<0.05$ \\
\hline
\end{tabular}

Table 7. Health awareness in the surveyed teachers (per 100 respondents)

\begin{tabular}{|c|c|c|c|c|c|}
\hline \multirow{2}{*}{ № } & \multirow{2}{*}{ Health awareness } & \multirow{2}{*}{ In total } & \multicolumn{2}{|c|}{ Burnout syndrome } & \multirow{2}{*}{$\begin{array}{c}\text { Probability of accurate } \\
\text { prediction } p\end{array}$} \\
\hline & & & Severe & Mild & \\
\hline 1 & Sedentary lifestyle & 64.9 & 72.1 & 52.7 & $<0.01$ \\
\hline 2 & Unhealthy or irregular diet & 57.1 & 66.4 & 42.8 & $<0.01$ \\
\hline 3 & Overweight & 56.4 & 64.9 & 42.9 & $<0.01$ \\
\hline 4 & Dissatisfaction with sleep quality & 54.7 & 60.7 & 43.7 & $<0.01$ \\
\hline 5 & No intention to normalize weight & 47.3 & 54.7 & 34.9 & $<0.01$ \\
\hline 6 & Lack of night's sleep & 46.8 & 58.2 & 30.4 & $<0.01$ \\
\hline 7 & Adherence to medical advice & 39.6 & 43.6 & 30.6 & $<0.01$ \\
\hline 8 & Use of sleeping pills & 37.2 & 44.1 & 25.3 & $<0.05$ \\
\hline 9 & Seeing a doctor due to health problems & 23.4 & 31.7 & 10.1 & $<0.01$ \\
\hline
\end{tabular}


Because the significant role in BS development is played by the psychological and emotional state, psychologists should be also involved in providing care for teachers employed by higher educational institutions.

\section{CONCLUSIONS}

More than half of the humanities teachers employed by higher educational institutions have symptoms of emotional burnout, complain of fatigue, regular headaches, back or chest pain, deteriorating memory, and low productivity. Among the factors that contribute to the development of this condition are low health awareness, unwillingness to consult a doctor or follow medical advice, irregular or unhealthy meals, lack of physical activity, and use of unprescribed medications. To prevent BS, measures should be taken aimed at improving health literacy among teachers and motivating them to seek and follow medical advice.

\section{References}

1. Piktushanskaja IN. O sostojanii professional'noj zabolevaemosti i invalidnosti vsledstvie profzabolevanij, kachestve periodicheskih medicinskih osmotrov $v$ Rostovskoj oblasti. Informacionny] sbornik statisticheskih, analiticheskih i normativnyh materialov. Rostov-na-Donu, 2002; $28 \mathrm{~s}$.

2. Pahomov VF. Analiz professional'noj zabolevaemosti $v$ otrasli ot vozdejstvija vibracii. Rekomendacii po snizheniju zabolevaemosti vibracionnoj bolezn'ju v otrasli i perevodu rabochih vibroopasnyh professij na drugie vidy rabot. M.: NIAT, 1987; 3-12.

3. Izmerov NF, Denisov Jel, redaktory. Rukovodstvo. Professional'ny] risk dlja zdorov'ja rabotnikov. M.: Trovant, 2003; 448 s.

4. Izmerov NF, Denisov Jel, Prokopenko LV, Sivochalova OV Stepanjan IV, Chelishheva MJu i dr. Metodologija vyjavlenija profilaktiki zabolevanij, svjazannyh s rabotoj. Medicina truda promyshlennaja jekologija. 2010; (9): 1-7.

5. Nauchnyj sovet \# 45 «Mediko-jekologicheskie problemy zdorov'ja rabotajushhih» RAMN 13 maja 2010 g. Metodicheskie rekomendacii. Metodologija vyjavlenija i profilaktiki zabolevanij, svjazannyh s uslovijami truda. M.: NII MT RAMN, 2010; 24 s.

6. Prokopenko LV, Kravchenko OK, Kostenko NA, Kirillov VF Profilaktika neblagoprijatnogo vozdejstvija vibroakusticheskih faktorov v sovremennyh uslovijah. Aktual'nye problemy «Mediciny truda». Sbornik trudov instituta. Pod redakciej akademika RAN NF. Izmerova i professora IV. Buhtijarova. 2015: 68-70.

7. Buhtijarov IV. Osnovy informacionnoj gigieny: koncepcii i problemy

\section{Литература}

1. Пиктушанская И. Н. О состоянии профессиональной заболеваемости и инвалидности вследствие профзаболеваний, качестве периодических медицинских осмотров в Ростовской области. Информационный сборник статистических, аналитических и нормативных материалов. Ростов-на-Дону, 2002; 28 c.

2. Пахомов В. Ф. Анализ профессиональной заболеваемости в отрасли от воздействия вибрации. Рекомендации по снижению заболеваемости вибрационной болезнью в отрасли и переводу рабочих виброопасных профессий на другие виды работ. М.: НИАТ, 1987; 3-12.

3. Измеров Н. Ф., Денисов Э. И., редакторы. Руководство. Профессиональный риск для здоровья работников. М.: Тровант, 2003; 448 c.

4. Измеров Н. Ф., Денисов Э. И., Прокопенко Л. В., Сивочалова О. В., Степанян И. В., Челищева М. Ю. и др. Методология выявления и просилактики заболеваний, связанных с работой. Медицина труда и промышленная экология. 2010; (9): $1-7$

5. Научный совет № 45 «Медико-экологические проблемь здоровья работающих» РАМН 13 мая 2010 г. Методические рекомендации. Методология выявления и профилактики заболеваний, связанных с условиями труда. М.: НИИ МТ РАMН, 2010; 24 c.

6. Прокопенко Л. В., Кравченко О. К., Костенко Н. А., Кириллов В. Ф. Просилактика неблагоприятного воздействия виброакустических факторов в современных условиях. Актуальные проблемы «Медицины труда». Сборник трудов института. Под редакцией академика РАН Н. Ф. Измерова и

innovacij. Gigiena i sanitarija. 2014; (4): 5-9.

8. Denisov Jel. Informacija kak fizicheskij faktor: problemy izmerenija, gigienicheskoj ocenki i IT-avtomatizacii. Medicina truda i promyshlennaja jekologija. 2014; (1): 36-43.

9. Eremin AL. Problema fiziologo-gigienicheskoj ocenk informacionnyh nagruzok dlja optimizacii truda [dissertacija]. M. 2014.

10. Stepanjan IV. Algoritmy optimizacii intellektual'nogo truda metodami vizualizacii informacii s pomoshh'ju kognitivnoj semanticheskoj grafiki. Nejrokomp'jutery: razrabotka i primenenie. 2014; (7): 53-9.

11. II'chenko JuG. Gigienicheskaja ocenka sostojanija zdorov'ja uchitelej srednih obshheobrazovatel'nyh uchrezhdenij [dissertacija]. Rostov-na-Donu, 2006; $25 \mathrm{~s}$.

12. Muhtarova LR. Kompleksnaja ocenka vlijanija faktorov vneshnej $i$ vnutrennej sredy na sostojanie zdorov'ja uchitelej (na primere g. Lipecka) [dissertacija]. M., 2005.

13. Kosarev II, Shurupova R. V. Kto dolzhen obuchat' studentov. Sechenovskij vestnik. 2014; 1 (15): 99-101.

14. Peniker OV. Sindrom professional'nogo vygoranija i ego profilaktika. Psihologija. Trudy SGA. 2008; (11): 32-40.

15. Skugarevskaja MM. Sindrom jemocional'nogo vygoranija. Medicinskie novosti. 2002; (7): 3-9.

16. Koroleva EG, Shhuster Jel. Sindrom jemocional'nogo vygoranija. Zhurnal GrGMU. 2007; (3): 108-11. профрессора И. В. Бухтиярова. 2015: 68-70.

7. Бухтияров И. В. Основы информационной гигиены: концепции и проблемы инноваций. Гигиена и санитария. 2014; (4): 5-9.

8. Денисов Э. И. Информация как фризический фактор: проблемы измерения, гигиенической оценки и ИТавтоматизации. Медицина труда и промышленная экология. 2014; (1): 36-43.

9. Еремин А. Л. Проблема физиолого-гигиенической оценки информационных нагрузок для оптимизации труда [диссертация]. М., 2014.

10. Степанян И. В. Алгоритмы оптимизации интеллектуального труда методами визуализации информации с помощью когнитивной семантической графики. Нейрокомпьютеры: разработка и применение. 2014; (7): 53-9.

11. Ильченко Ю. Г. Гигиеническая оценка состояния здоровья учителей средних общеобразовательных учреждений [диссертация]. Ростов-на-Дону, 2006; 25 с.

12. Мухтарова Л. Р. Комплексная оценка влияния фракторов внешней и внутренней среды на состояние здоровья учителей (на примере г. Липецка) [диссертация]. М., 2005.

13. Косарев И. И., Шурупова Р. В. Кто должен обучать студентов. Сеченовский вестник. 2014; 1 (15): 99-101.

14. Пеникер О. В. Синдром профессионального выгорания и его просилактика. Психология. Труды СГА. 2008; (11): 32-40.

15. Скугаревская М. М. Синдром эмоционального выгорания. Медицинские новости. 2002; (7): 3-9.

16. Королева Е. Г., Щустер Э. И. Синдром эмоционального выгорания. Журнал ГрГМУ. 2007; (3): 108-11. 